«Системні технологіï» 2 (127) 2020 «System technologies»

DOI 10.34185/1562-9945-2-127-2020-08

UDC 519.25:681.5

O.P. Sarychev, B.A. Perviy

\title{
AUTOREGRESSION MODELS OF SPACE OBJECTS MOVEMENT REPRESENTED BY TLE ELEMENTS
}

Annotation. The developed method, which is a modification of the previously developed methods for constructing autoregressive models, is used to simulate the motion of space objects in the time series of their TLE elements. The modeling system has been developed that includes: determining the optimal volume of training samples in modeling time series of TLE elements; determination of the autoregression order for each variable (TLE element); determination of the optimal structure and identification of the parameters of the autoregressive model for each variable; identification of patterns of evolution of the mean square error of autoregressive models in time based on the modeling of time series of TLE elements according to the principle of "moving interval".

Keywords: Orbit Propagation; SGP4; TLE; Regression.

Introduction. The problem of improving the accuracy of forecasting the satellite position is relevant for the tasks of determining time of their existence, cataloging space debris, navigation, etc. To solve this problem, physical approaches are mainly used, but they require complete information about the space object at the beginning of the trajectory and environment calculations, as well as data on the maneuvers of the object under study [1]. In all cases, such data is not complete or is not updated regularly, and current observational capabilities are limited or costly.

The only open source of orbital data for solving such problem are the two- line elements (TLE), which regularly and promptly updated on the website of the American Space Monitoring System (SSS) [1]. The values of the orbit parameters contained in TLE files are calculated using averaging within the framework of specific SGP4 models (Simplified General Perturbations models for calculating the position and speed of the Earth's orbiting satellite, with an orbital period of less than 225 minutes) or SDP4 (Simplified Deep

(C) Sarychev O.P., Perviy B.A., 2020 


\section{«Системні технології» 2 (127) 2020 «System technologies»}

Space Perturbations - models for calculating the position and speed of the Earth's orbiting satellite, with an orbital period of more than 225 minutes) [2].

Several studies which represents different approaches to orbit propagation using TLE elements are investigated as well.

Various machine learning methods and hybrid methods are quite successfully used for solving problems of propagating and predicting the motion of space objects, among them neural network methods, Kalman filter and support vector method. In [3], a neural network was used to increase the accuracy of the analytical predictor. As a result, a combination of both methods reduces the error in calculating the position of a space object and improves the accuracy of predicting its motion. In [4], the main emphasis was placed on the Data Mining approach and the extraction of historical data on unknown disturbances using the extended Kalman filter. This approach improved the quality of filtration and prediction, but only for space objects in low Earth orbits.

An approach based on distributed regression and transitional machine learning underlies the publication [5]. The result shows superiority over the extended Kalman filter. In addition, the method is able to evaluate significantly changing parameters of the orbit.

In [6]-[8], Keplerian orbital elements are used as initial estimates of TLE elements using differential corrections and nonlinear least squares methods. In [9], a Kalman filter was used to estimate TLE elements using GPS data. The above methods look for a local minimum of the objective function, representing the sum of the squares of the position and velocity errors and depend on the initial estimate of the TLE elements. Methods such as genetic [10] and IWO (Invasive Weed Optimization) algorithms [11] do not require an initial assessment of TLE elements, but they are reportedly computationally expensive because they seek for a global optimum.

In the literature, there are two main approaches for evaluating TLE elements: machine- costing methods for searching for global optimum and methods for searching for local optimum, which depend on the initial estimate of TLE elements. The developed autoregressive models [18] offer an alternative, less machine- expensive method for improving the forecast, and 104 
«Системні технології» 2 (127) 2020 «System technologies»

their expected errors do not exceed the error rates presented above the models.

The purpose of the work is to establish the possibility of using autoregressive models fofr orbit propagation of space objects represented by the time series of TLE elements (Two- Line Elements).

\section{Major part}

1 Modeling the motion of space objects represented by time series of TLE elements

A distinctive feature of TLE- elements series is their time positioning not on a uniform temporal grid, but with irregular time intervals between observations, so- called "unequal observations". This feature was taken into account in the development of a method for estimating the parameters of autoregressive models with unequal- time observations for orbit propagation of large fragments of space debris [13]. The developed method, which is a modification of previously developed methods for constructing autoregressive models [14]-[16], is used to simulate the motion of space objects in the time series of their TLE elements.

The construction of statistical models was carried out on the basis of an iterative procedure for estimating the coefficients of beta- autoregressive models under conditions of unequally spaced observations [13]. The time series of TLE elements are represented by seven main and three additional variables (see Table 1).

Table 1

List of variables for Sich- 2 TLE data

\begin{tabular}{|c|l|l|}
\hline Designation & \multicolumn{1}{|c|}{ Title } & \multicolumn{1}{|c|}{ Unit of measurement } \\
\hline$x_{1}$ & Apogee & $\mathrm{km}$ \\
\hline$x_{2}$ & Perigee & $\mathrm{km}$ \\
\hline$x_{3}$ & Eccentricity & - \\
\hline$x_{4}$ & Inclination & $\mathrm{deg}$ \\
\hline$x_{5}$ & Right ascension of the ascending node & $\mathrm{deg}$ \\
\hline$x_{6}$ & Argument of perigee & $\mathrm{deg}$ \\
\hline$x_{7}$ & Mean anomaly & $\mathrm{deg}$ \\
\hline$x_{8}$ & Revolution number at epoch & revs \\
\hline$x_{9}, t_{n a k}$ & Accumulated time & $\mathrm{hrs}$ \\
\hline$x_{10}, \tau_{i}$ & $\begin{array}{l}\text { The time interval between the current } \\
\text { and the previous observation }\end{array}$ & $\mathrm{hrs}$ \\
\hline
\end{tabular}




\section{«Системні технологіï» 2 (127) 2020 «System technologies»}

Modeling was carried out for six main variables, since the variable $x_{4}$ -inclination had, as a rule, a constant value. Additional variables $x_{8}, x_{9}$ were used to construct the figures, and the variable $x_{10}$ was used to calculate the degree of which the components of the coefficients are powered in the estimation procedure [13].

Trial calculations based on the iterative procedure [13] of the method of structural- parametric identification in the class of beta- autoregressive models found that in this problem the maximum number of previous values of output variables $x_{1}, x_{2}, \ldots, x_{7}$ that affect their current value is sufficient to choose equal $p=7$, since the improvement in the quality of models with a further increase of $p$ turned out to be inconsequential.

In accordance with the developed method of structural and parametric identification of the ratios of weight coefficients for autoregressors in the beta- autoregressive model, we set a special weight function determined on the basis of a two- parameter probability density function of the beta distribution, for which the parameter $\alpha$ is fixed $-\alpha=1$, and the parameter $\beta$ can take integer values $\beta=1,2, \ldots, \beta_{\max }$, where $\beta_{\max }$ - set value.

The larger the value of the parameter $\beta$, the greater the excess of the weight coefficient at the first previous value of the variable over the coefficients at the earlier previous values. The graphs of the weight functions for the values $\beta=1,3, \ldots, 25$ for $p=7$ are shown in Fig. 1 .

For $\beta=1$ weight coefficients with autoregressors are the same: $a_{j}=1 / 7, j=1,2, \ldots, 7$. With increase $\beta$, the weight coefficient at the first previous value becomes predominant. So, with the value $\beta=13$, the weight of the first "delay" in the model is approximately 0.90 , and the sum of the weights of all other delays (their number is $p-1=6$ ) is approximately 0.10 . When $\beta=25$ the weight of the first delay is approximately 0.99 , and the sum of the weights of all other delays is approximately 0.01 . 
«Системні технології» 2 (127) 2020 «System technologies»

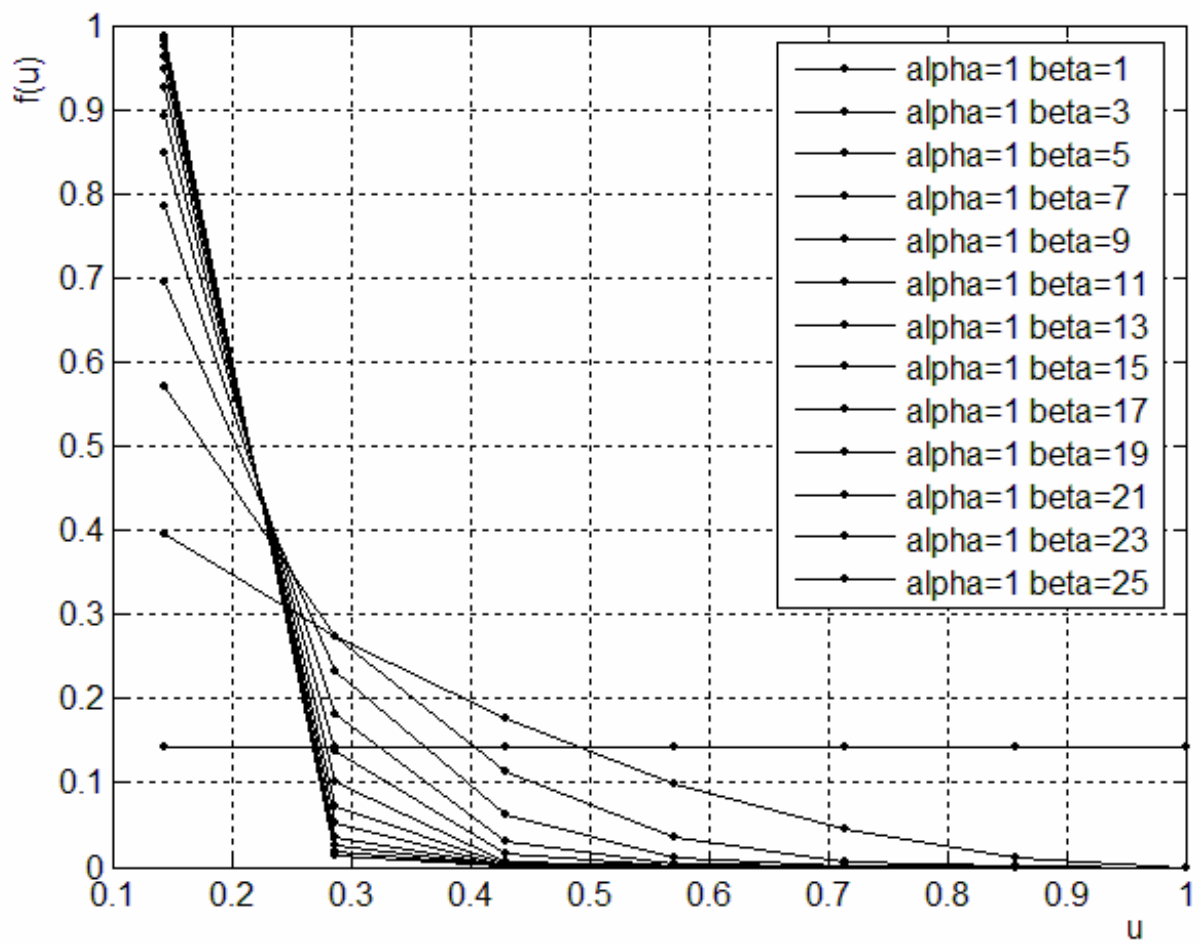

Figure 1 -Weight functions of coefficients for beta autoregression $(p=7)$ (weight functions are presented as values of probability density functions $f(u)$ for a random variable $u$ having beta distribution)

By constructing beta- autoregressive models for all $\beta=1,3, \ldots, 25$, it is possible to identify the best weight function that corresponds to the lowest residual standard error (RMS) of the model. In fact, we can say that by determining the optimal value of the parameter $\beta$ at which the mean square error is minimal, we thereby solve the problem of choosing the optimal structure of the model.

By dividing the entire observation period into intervals corresponding to cycles of variation of the main variables $x_{5}, x_{6}, x_{7}$, and solving the structural- parametric identification problems based on [13], we can identify changes in the structure (type of weight function), coefficients, and meansquare error of the best model for all the main variables, depending from the interval number. By analyzing the graphs of these changes, it is possible to identify features and general patterns of behavior of the main variables of different objects during the observation period. 
«Системні технології» 2 (127) 2020 «System technologies»

2 Analysis of the results of modeling the movement of objects represented by time series of TLE elements

In accordance to the described calculation procedure autoregressive models are constructed for the following space objects: 1) SICH1 \#23657, 2) SICH2 \#37794, 3) XTE \#23757, 4) POLYITAN- 1 \#40042, 5) POLYITAN- 2SAU \#42732, 6) MINOTAUR RB \#26066 (five spacecraft and one spent launch vehicle stage).

The simulation results are presented in Fig. 2-7, where the dependences of the mean square error (RMS) of the constructed models for six objects are given for 6 main variables. The standard deviations of the constructed models are: for apogee and perigee $(2-7) \mathrm{m}$, for eccentricity $(0.6-1.0) \cdot 10^{-5}$, for the longitude of the ascending node $(0.2-1.2)$ degrees, for the argument perigee $(1.0-1.5)$ degrees, for the average anomaly $(1.0-2.0)$ degrees.

Conclusion. Based on the results obtained in the process of modeling of several space objects, a modeling system has been developed including: determining the optimal quantity of training samples in modeled time series of TLE elements; determination of the autoregression order for each variable (TLE element); determination of the optimal structure and identification of the parameters of the autoregressive model for each variable; identification of patterns of evolution of the mean square error of autoregressive models in time based on the modeling of time series of TLE elements according to the principle of "sliding interval".

It was established that model's standard deviations are: for apogee and perigee $(2-7) \mathrm{m}$, for eccentricity $(0.6-1.0) 10^{-5}$, for the longitude of the ascending node $(0.2-1.2)$ degrees, for the argument of perigee $(1.0-1.5)$ degrees, for the average anomaly $(1.0-2.0)$ degrees. In some sections of the time series, model errors take values that significantly exceed the values from the given ranges. These excesses can be used as signs of an unexpected change in the motion mode of a space object. 
«Системні технології» 2 (127) 2020 «System technologies»
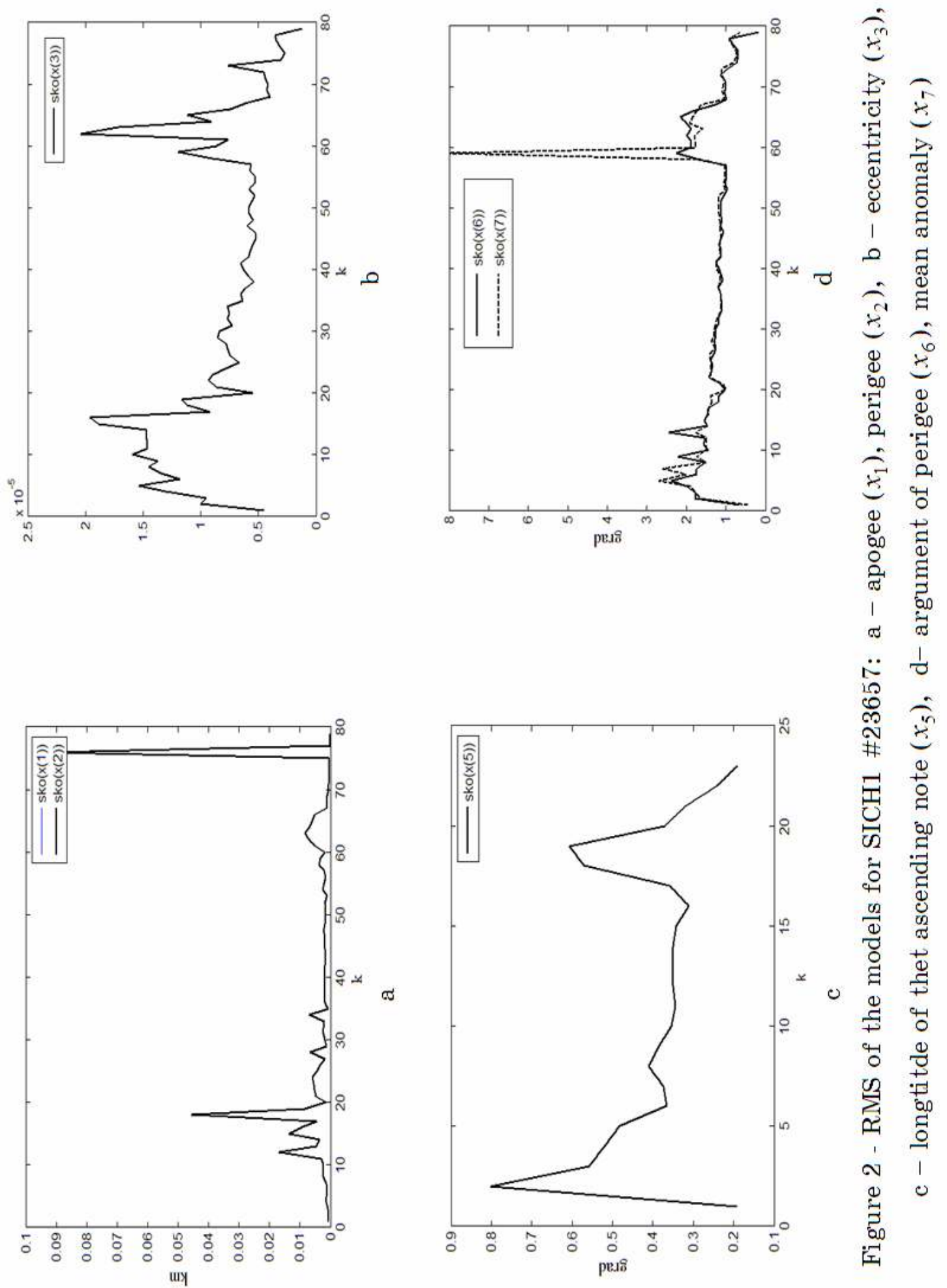
«Системні технологіï» 2 (127) 2020 «System technologies»
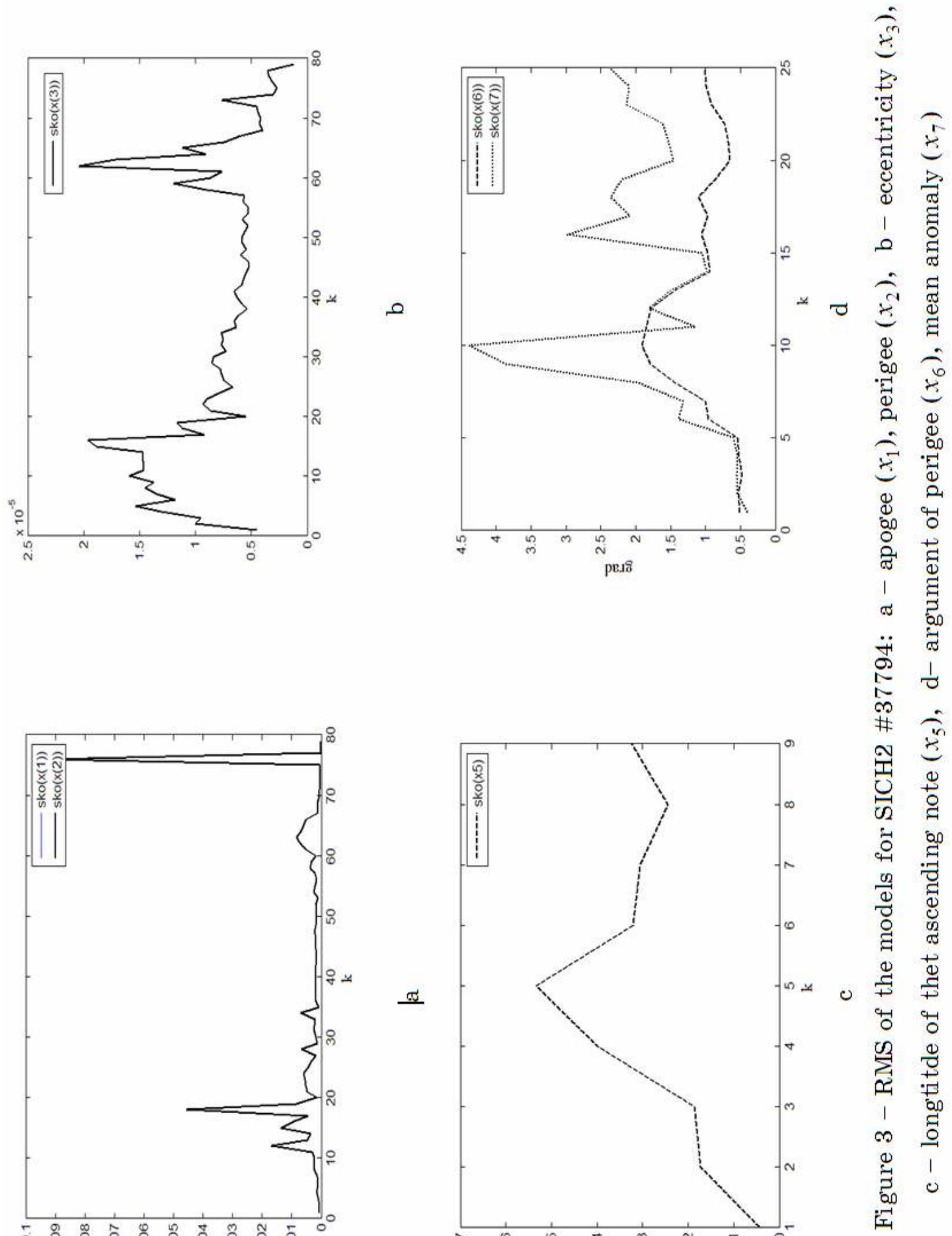
«Системні технології» 2 (127) 2020 «System technologies»
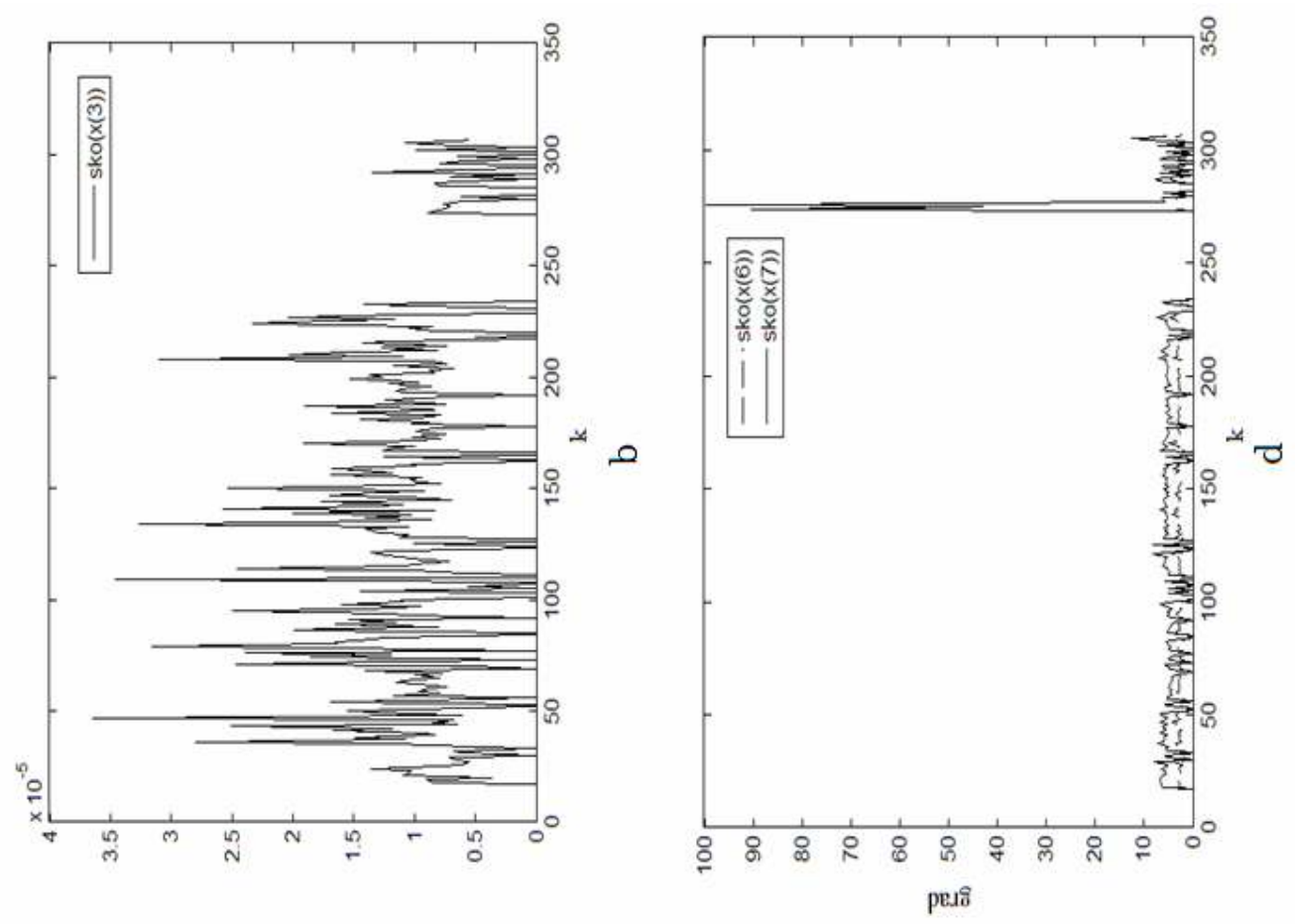

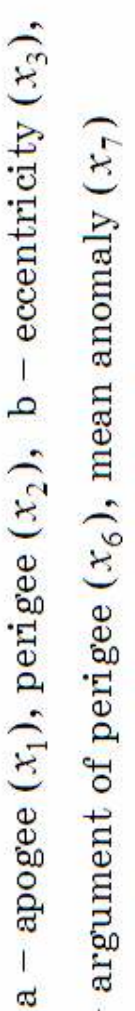
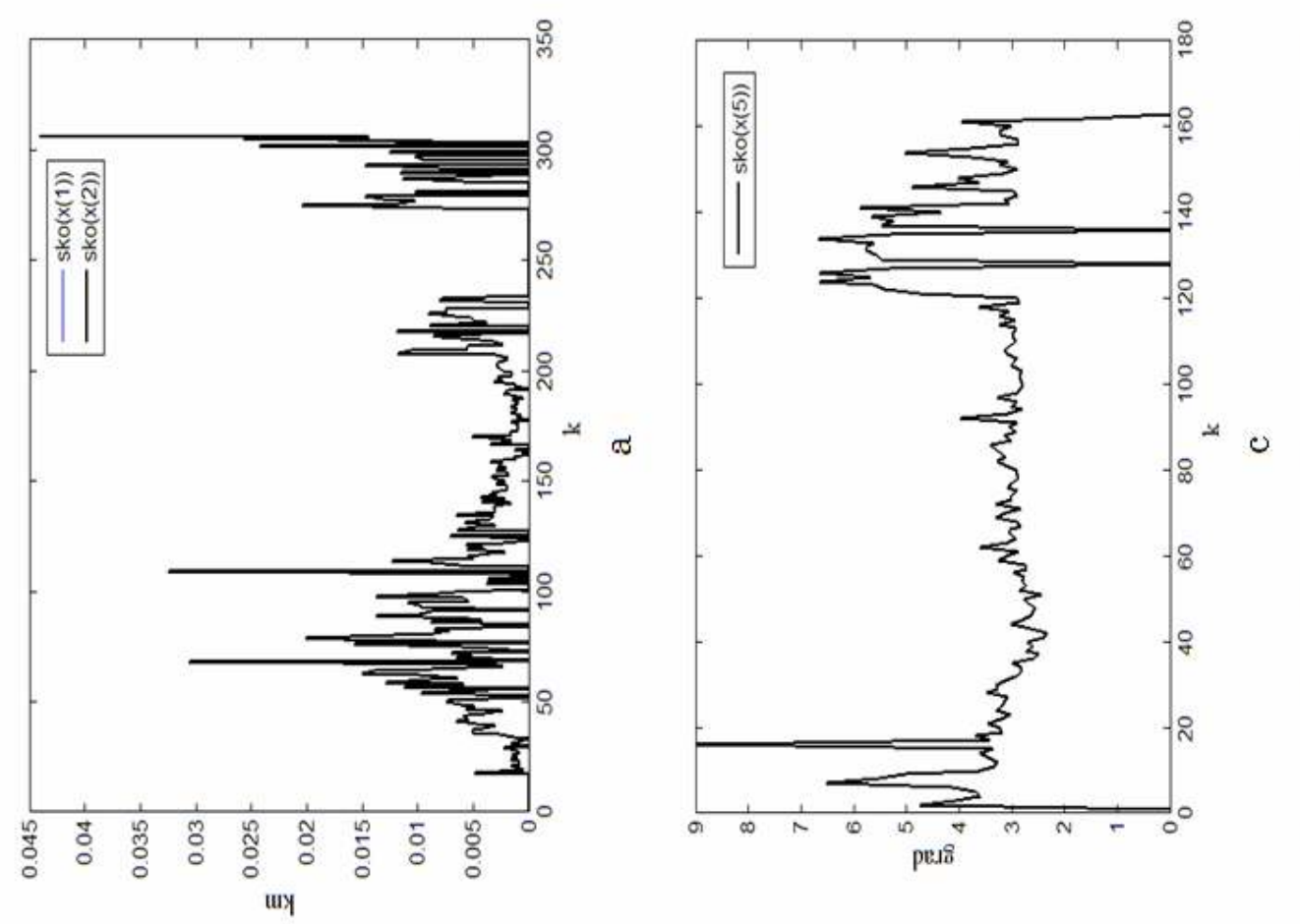

$\therefore$ t

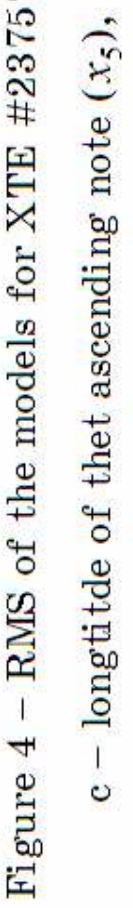


«Системні технології» 2 (127) 2020 «System technologies»
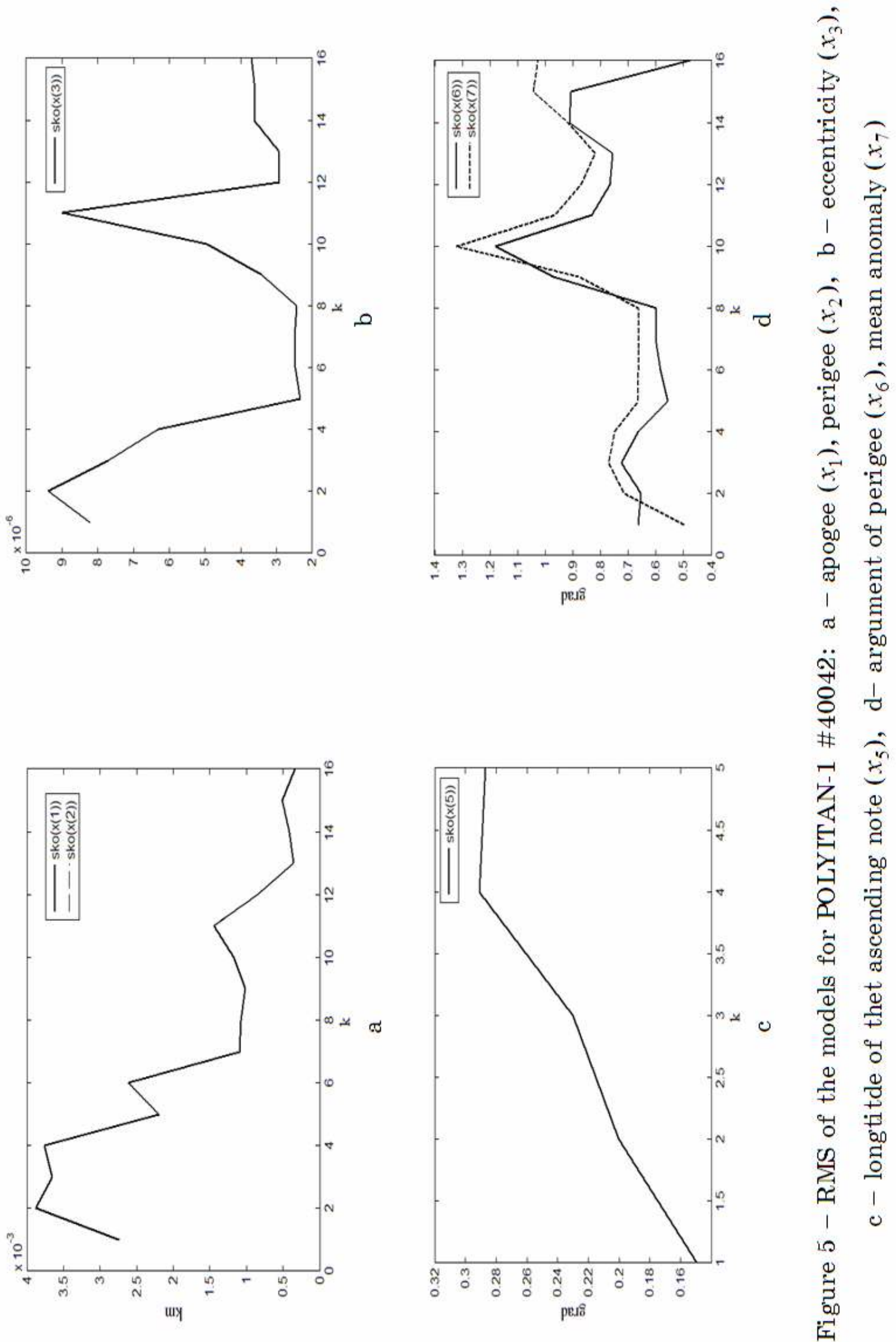

112 
«Системні технології» 2 (127) 2020 «System technologies»
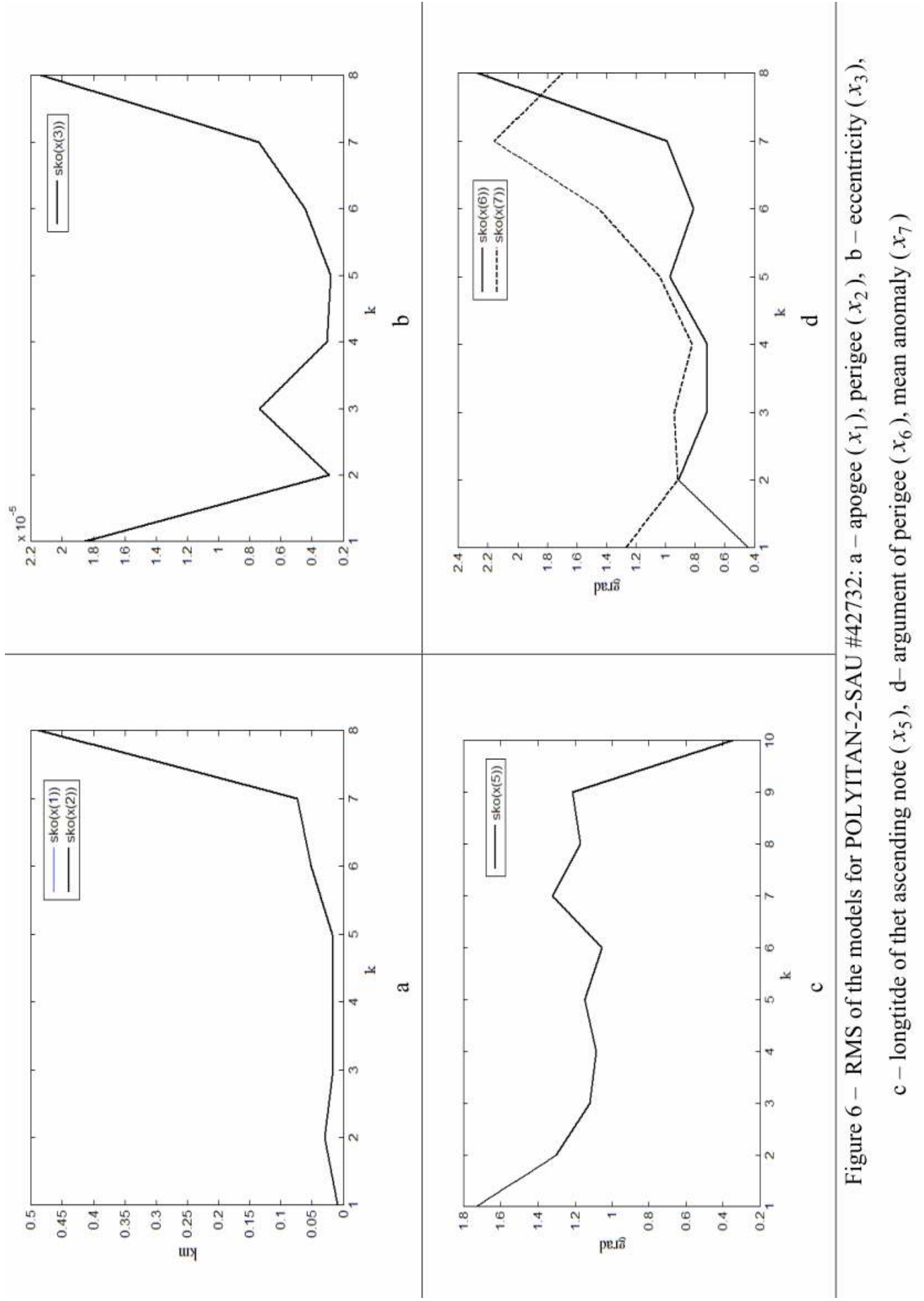
«Системні технологіï» 2 (127) 2020 «System technologies»
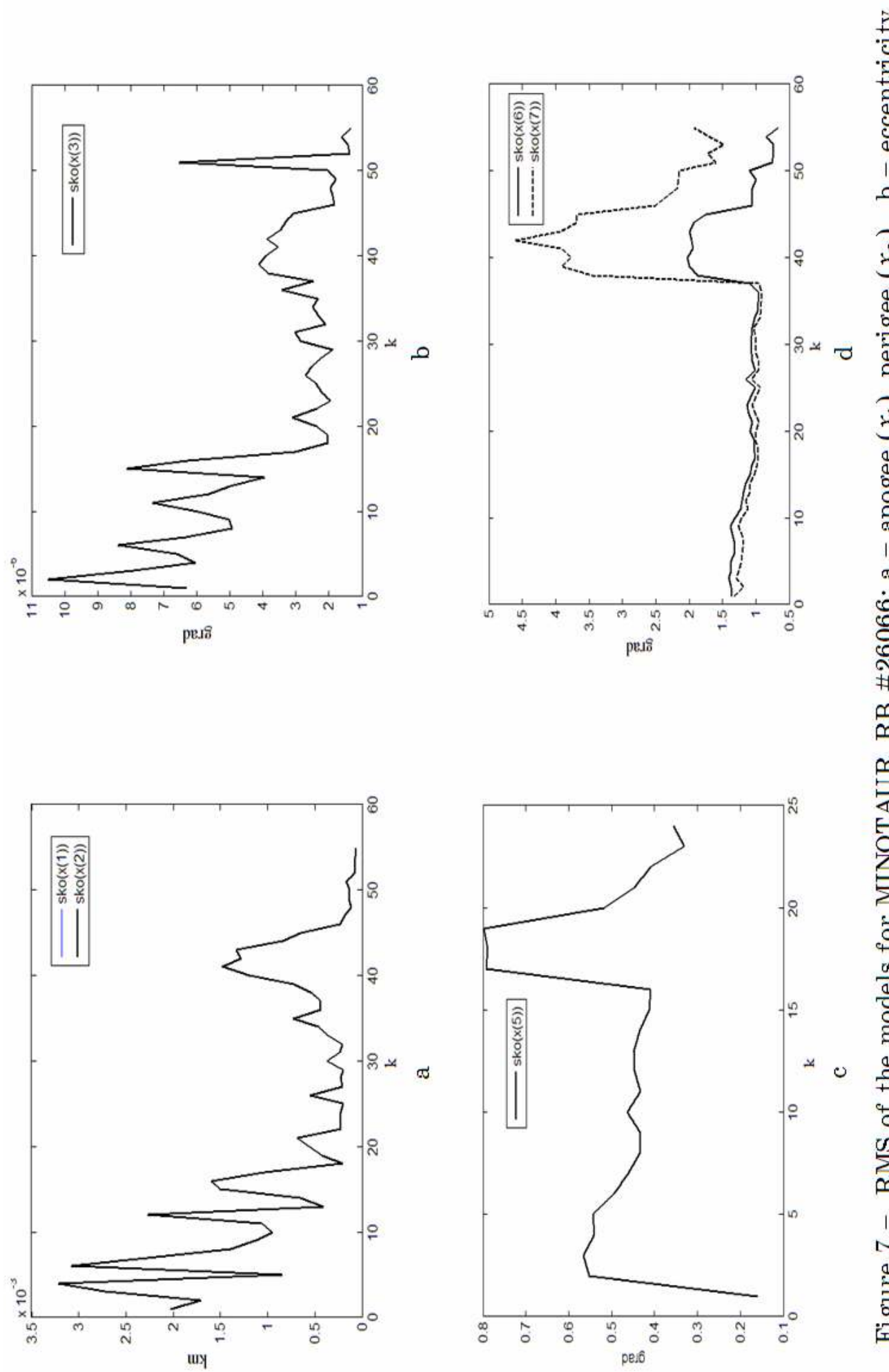

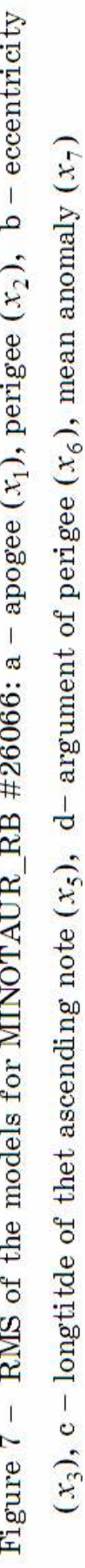




\section{«Системні технологіï» 2 (127) 2020 «System technologies»}

\section{REFERENCES}

1. Luo Y.Z. A Review of Uncertainty Propagation in Orbital Mechanics / Y.Z. Luo // Progress in Aerospace Sciences, 2017. -C. 89.

2. Vallado D.A. Fundamentals of astrodynamics and applications, 4th / D.A. Vallado. -Microcosm Press, 2013.

3. Pérez I. Application of Computational Intelligence in Order to Develop Hybrid Orbit Propagation Methods / I. Perez, J. F. San- Juan, M. San- Martin, L. M. López- Ochoa // Mathematical Problems in Engineering, 2013.

4. Shou H. N. Orbit Propagation and Determination of Low Earth Orbit Satellites. International Journal of Antennas and Propagation, 2014.

5. Sharma S. Robust Orbit Determination and Classification: A Learning Theoretic Approach. / S. Sharma, J. Cutler // IPN Progress Report, 2015.

6. Vallado D. Sgp4 orbit determination // D. Vallado, P. Crawford. -2008.

Jochim E. Gps based onboard and onground orbit operations for small satellites / E. Jochim, E. Gill, O. Montenbruck, M. Kirschner // Acta Astronautica. Вип. 39(9- 12). -1996.

7. Lee B. Norad tle conversion from osculating orbital element / B. Lee // Journal of Astronomy and Space Sciences. -2002. -Вип.19, №4.

8. Montenbruck O. Real- time estimation of sgp4 orbital elements from gps navigation data / O. Montenbruck, E. Gill. -C. 26-30. -2000.

9. Goh S.T. Real- time estimation of satellite's two- line elements via positioning data / S.T. Goh, K.S. Low. -C. 1- 7. -2018.

10. Bolandi H. Estimation of simplified general perturbations model for orbital elements from global positioning system data by invasive weed optimization algorithm / H. Bolandi, M. Molandi, L. Ashtari, S. Sedighy, M. Zeighami, M. Esmailzadeh // Proceedings of the Institution of Mechanical Engineers, Part G: Journal of Aerospace Engineering. -2015. -Вип. 229, №8. -С. 1384.

11. FSCC TLE Source [Електронний ресурс]. -Режим доступа https://www.space- track.org/\#Landing

12. Sarychev O. P. Optimal regressors search subjected to vector autoregression of unevenly spaced TLE series / O. P. Sarychev, B. A. Perviy, // Системні технології. -Випуск 2 (121). -2019. -C. 95-110.

13. Alexander P. Sarychev Modeling in the Class of Systems of Regression Equations by the Group Method of Data Handling / A. P. Sarychev // Journal of Automation and Information Sciences. -Begell House Inc. -2013. -Volume 45, Number 3. -P. 4-22.

14. Sarychev A. P. Modeling in the Class of Autoregression Equations Systems in Conditions of Structural Uncertainty / A. P. Sarychev // Journal of Automation and Information Sciences. -Begell House Inc. -2015. -Volume 47, Number 7. -P. 59-88. 
«Системні технології» 2 (127) 2020 «System technologies»

15. Sarychev A. P. Modelirovanie slozhnyih sistem v usloviyah strukturnoy neopredelYonnosti: regressionnyie i avtoregressionnyie modeli / A. P. Sarychev // LAP LAMBERT Academic Publishing RU, Saarbrücken, Deutschland. $-2016 .-274 \mathrm{c}$.

Received 12.02.2020. Accepted 18.02.2020.

Авторегрессионные модели движения космических объектов, представленных временными рядами TLE- элементов

Разработанный метод, представляющий собой модификацию разработанных ранее методов построения авторегрессионных моделей, применён для моделирования движения космических объектов по временным рядам их TLE- элементов. На основе результатов, полученных в процессе моделирования группы космических объектов, разработана система моделирования, которая включает в себя: определение оптимального объёма обучающих выборок при моделировании временных рядов TLEэлементов; определение порядка авторегрессии для каждой переменной (TLEэлемента); определение оптимальной структуры и идентификация параметров модели авторегрессии для каждой переменной; выявление закономерностей эволюции среднеквадратичной ошибки авторегрессионных моделей во времени на основе моделирования временных рядов TLE- элементов по принципу "скользящего интервала".

Autoregression models of space objects movement represented by TLE-elements

The developed method, which is a modification of the previously developed methods for constructing autoregressive models, is used to simulate the motion of space objects in the time series of their TLE elements. The modeling system has been developed that includes: determining the optimal volume of training samples in modeling time series of TLE elements; determination of the autoregression order for each variable (TLE element); determination of the optimal structure and identification of the parameters of the autoregressive model for each variable; identification of patterns of evolution of the mean square error of autoregressive models in time based on the modeling of time series of TLE elements according to the principle of "moving interval".

Сарычев Александр Павлович - д.т.н., ведущий научный сотрудник, Институт технической механики НАН Украины и ГКА Украины.

Первый Богдан Андреевич - младший научный сотрудник, Институт техничной механики НАН Украины и ГКА Украины.

Саричев Олександр Павлович - д.т.н., провідний науковий співробітник, Інститут технічної механіки НАН України і ДКА України.

Первій Богдан Андрійович - молодший науковий співробітник, Інститут технічної механіки НАН України і ДКА України.

Sarichev Aleksandr - Doctor of Technical Science, Institute of Technical Mechanics of the National Academy of Sciences of Ukraine and State Space Agency of Ukraine.

Perviy Bogdan - Junior Researcher, Institute of Technical Mechanics of the National Academy of Sciences of Ukraine and State Space Agency of Ukraine of Ukraine. 